\title{
Evaluation of Facial and Dental Midline Discrepancies in
} Nepalese Population

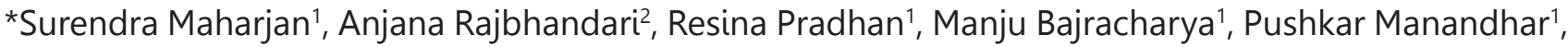 \\ Bashu Dev Pant ${ }^{1}$
}

Author Info:

${ }^{1}$ Assistant Professor, ${ }^{2}$ Professor; Department of Orthodontics and Dentofacial Orthopedics, People's Dental College and Hospital, Sorhakhutte, Kathmandu

\section{*Corresponding Author: \\ Dr. Surendra Maharjan \\ Email/Contact:}

maharjan.surendra@gmail.com $+9779860462377$

\section{ABSTRACT}

Background: The facial midline is defined by the landmark such as the nose, philtrum, and chin aligned in a straight line. It should be in the center of the face and should coincide with the dental midline. But clinically it is often observed that some discrepancies exist between facial and dental midlines. Thus the aim of this study was to evaluate the facial and dental midline discrepancies.

Methods: A total of 300 subjects, 150 male and 150 female from People's Dental College and Hospital were selected. Full facial view standardized photograph with a posed smile with teeth in occlusion was taken with Canon 400D digital SLR. For standardized measurement vertical metallic scale with millimeter, markings were placed on the right side of the patient in all cases. The software program Digimizer image analysis (version 4.6.1) was used to determine the facial and maxillary dental midline.

Result: This study showed $6.66 \%$ of male and $12 \%$ of female had perfectly coinciding F1 facial midline (perpendicular from the midpoint of inner canthus distance), F2 facial midline (line joining the midpoint of inner canthus and the midpoint of the base of the nose) and maxillary midline. $26 \%$ of males and $28 \%$ of females had less than $1 \mathrm{~mm}$ of the discrepancy of F1 midline to maxillary midline whereas $41 \%$ of males and $38 \%$ of females had less than $1 \mathrm{~mm}$ of a discrepancy between F2 facial midline and maxillary midline. The study also showed that $24 \%$ of males and $24.66 \%$ of females had none coincidence of any of the midlines with one another.

Conclusion: Most of the Nepalese have noncoinciding facial and dental midline but females have more coinciding midlines in comparison to males. The shifted facial midlines are more towards the left side in relation to maxillary dental midline.

Keywords: Coincidence, Dental midline, Facial midlines

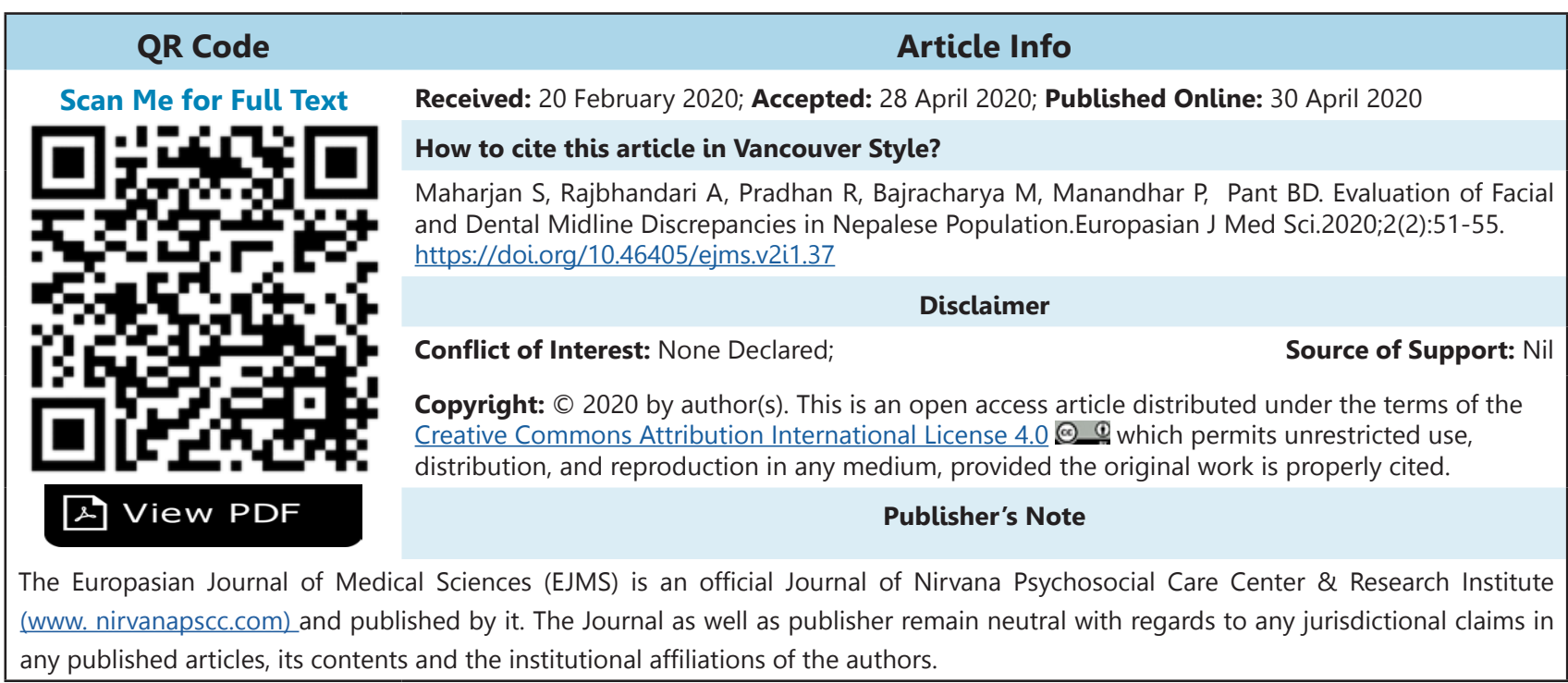




\section{INTRODUCTION}

Symmetry simply means balanced distribution of various parts around the common axis whereas asymmetry means imbalance in the distribution of parts ${ }^{1}$. Perfect symmetrical body including face seldom exists in living beings. Asymmetry can be either functional or morphological ${ }^{2}$. Asymmetrical face can be described as difference in shape and size of facial parts in two halves of the face ${ }^{3}$. Clinically facial asymmetry occurred in about $1 / 3$ of the dentofacial deformed population in which lower third of face was affected more than the upper and middle third of the face ${ }^{4}$.

In orthodontics, trends have been changing from Angle paradigm which focused mainly on ideal occlusion to soft tissue paradigm, focusing mainly on soft tissues and facial esthetics ${ }^{5}$. With increase in focus on facial esthetics, more concern on dental and occlusal asymmetries and midline discrepancies also increasing ${ }^{6}$. Any deviation from normal proportion and arrangement of face and teeth results in dentofacial asymmetry. Though minor asymmetry can be detected only thorough detail examination $n^{7}$. The facial midline is determined with the help of landmarks like nose, philtrum and chin aligned in a straight line while dental midline is determined with coinciding mid sagittal line of upper and lower arches during centric relation ${ }^{8}$. But clinically it is often observes that some discrepancies exist between facial and dental midlines ${ }^{9}$. Many researchers including Ernest L. Miller et al ${ }^{10}$ have noticed that facial and maxillary midline usually coincides whereas maxillary and mandibular midline does not ${ }^{11}$. Even the facial midline and symmetry is affected by the deviated nose as well12.

Most of the studies regarding these midlines were done in western population and much have not been done in Nepalese population. Thus the aim of this study was to evaluate the coincidence between facial midlines to maxillary dental midline, to calculate the amount of discrepancy between midlines and to determine the side of shift of facial and maxillary dental midline in Nepalese population.

\section{MATERIALS AND METHODS}

In the present study 300 subjects, both male and female, 150 each, of age above 17 years were selected from students, interns and the individuals who visited the Department of Orthodontics in People's Dental College and Hospital. Research was approved by the Institutional Review Committee of Institute of Medicine, Tribhuvan University (Ref No- 270/ (6-11) E2 076/077). Full facial view standardized photograph of posed smile with teeth in occlusion was taken. The digital camera (Cannon 400D digital SLR) was made fixed by mounting it on tripod. The distance between the subject and camera was kept fixed (4 feet) in all photographs. For standardized measurement vertical metallic scale with millimeter markings was placed on the right side of the patient in all cases. The software program Digimizer image analysis (version 4.6.1) was used to determine the facial and maxillary dental midline.



Figure 1: Facial smile photograph showing F1, F2 Facial midlines and maxillary midline

The first facial midline was drawn perpendicular from the midpoint of inner canthus distance as F1 facial midline and the second facial midline was drawn joining the midpoint of inner canthus and the midpoint of the base of the nose as F2 facial midline. The maxillary dental midline drawn through the tip of the incisal embrasure between the two maxillary central incisors (Figure 1). Finally distance between facial midlines, (F1 and F2) and maxillary dental midline were measured.

The inclusion criterions for the study were

- Age above 17 years. 
- All anterior teeth present with normal alignment.

- No history of congenital conditions or trauma affecting facial form and appearance.

- No history of orthodontic treatment.

The exclusion criterions of photographs were

- Images with bad resolution.

- Images with rotated head position.

- Visible asymmetry involving eyes.

- Linear smile (anterior teeth not visible on posed smile).

The data were collected and descriptive statistics were drawn from the quantitative data using the Statistical Package for Social Sciences (SPSS version 20.00, Chicago, Inc.).

\section{RESULTS}

Table 1 shows the comparison of midline discrepancies between F1 facial midline to maxillary

Table 1: Descriptive analysis of midline discrepancies

\begin{tabular}{|l|l|l|l|}
\hline Gender & Participants & Outcome & Percent \\
\hline Male & 150 & 10 & 6.66 \\
\hline Female & 150 & 18 & 12 \\
\hline
\end{tabular}

Table 3: Coinciding F1 and F2 facial midlines only

\begin{tabular}{c|c|c|c|}
\hline \multirow{2}{*}{ Gender } & $\begin{array}{c}\text { Position from } \\
\text { maxillary } \\
\text { dental } \\
\text { midline }\end{array}$ & Outcome & Percent \\
\hline \multirow{2}{*}{ Male } & Right & 10 & $6.7 \%$ \\
\cline { 2 - 4 } & Left & 28 & $18.7 \%$ \\
\hline \multirow{2}{*}{ Female } & Right & 16 & 10.6 \\
\hline & Left & 16 & 10.6 \\
\hline
\end{tabular}

midline and F2 facial midline to maxillary midline. While examining the coincidence of all midlines, only $6.66 \%$ of male and $12 \%$ of female had perfectly coinciding F1, F2 and maxillary midline (Table 2).

Table 3 represents the coincidence of F1 and F2 facial midlines only but not with the maxillary dental midline whereas Table 4 represents the coincidence of both facial midlines with maxillary dental midline separately.

Table 4: Coinciding F1, F2 facial midlines with Maxillary dental midline separately

\begin{tabular}{l|l|l|} 
Gender & $\begin{array}{l}\text { F1 with maxillary } \\
\text { dental midline }\end{array}$ & $\begin{array}{l}\text { F2 with maxillary } \\
\text { dental midline }\end{array}$ \\
\hline Male & $16(10.66 \%)$ & $21(14 \%)$ \\
\hline Female & $8(5.33 \%)$ & $26(17.33 \%)$
\end{tabular}

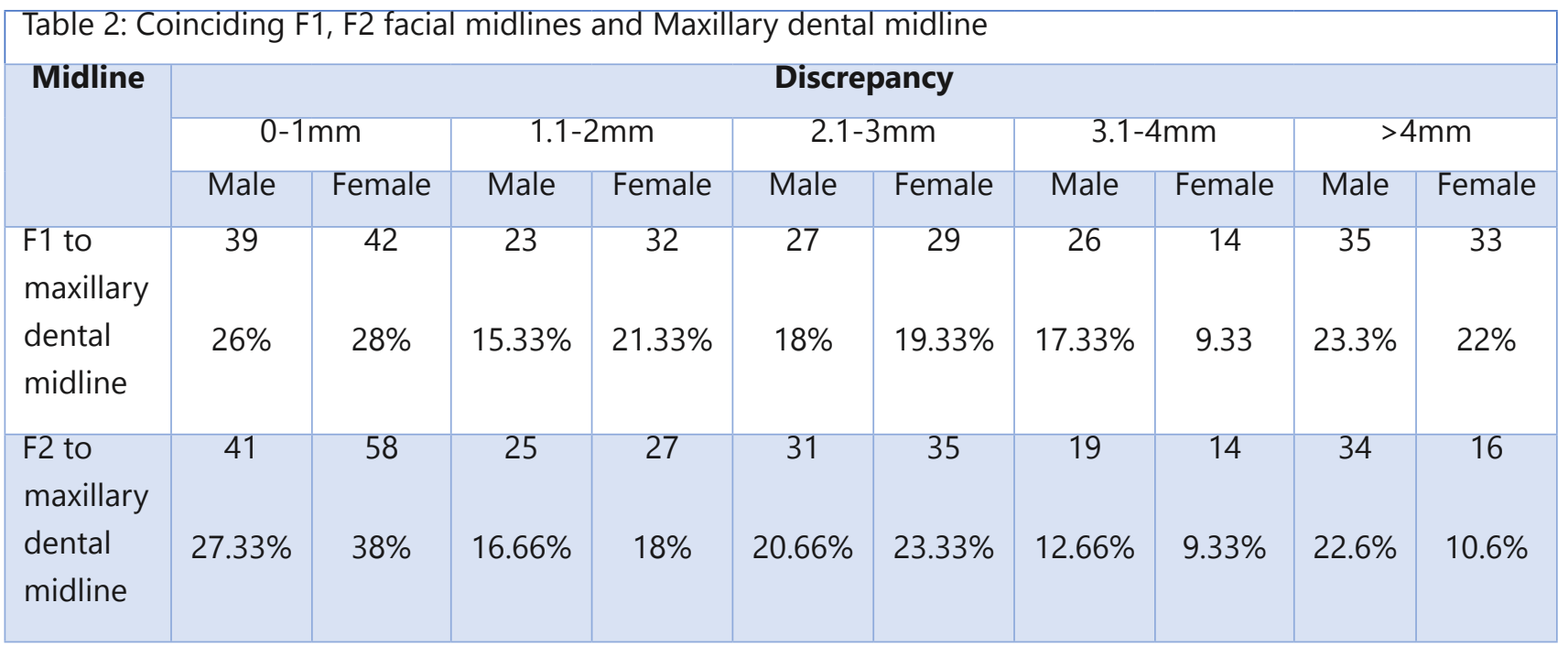




\begin{tabular}{|c|c|c|c|c|}
\hline \multicolumn{5}{|c|}{$\begin{array}{l}\text { Table 5: Shift of F2 than F1 facial midline on } \\
\text { same side }\end{array}$} \\
\hline \multirow[t]{2}{*}{ Gender } & \multicolumn{2}{|c|}{$\begin{array}{l}\text { Increased shift } \\
\text { of F2 }\end{array}$} & \multicolumn{2}{|c|}{$\begin{array}{l}\text { Decreased shift } \\
\text { of F2 }\end{array}$} \\
\hline & Right & Left & Right & Left \\
\hline Male & 6 (4\%) & $\begin{array}{l}7 \\
(4.66 \%)\end{array}$ & $\begin{array}{l}5 \\
(3.33 \%)\end{array}$ & $\begin{array}{l}11 \\
(7.33 \%)\end{array}$ \\
\hline Female & $\begin{array}{l}1 \\
(0.66 \%)\end{array}$ & $9(6 \%)$ & $\begin{array}{l}7 \\
(4.66 \%)\end{array}$ & $\begin{array}{l}12 \\
(8 \%)\end{array}$ \\
\hline
\end{tabular}

Table 5 shows the increased and decreased shift of F2 facial midline than initial F1 facial midline from maxillary midline. Table 6 represents the data regarding non coincidence of any of the midlines with one another which shows that $24 \%$ of male and $24.66 \%$ of female had the facial midlines on either side of the maxillary midline.

\begin{tabular}{|c|c|c|}
\hline Gender & Frequency & Percentage \\
\hline Male & 36 & $24 \%$ \\
\hline Female & 37 & $24.66 \%$ \\
\hline
\end{tabular}

\section{DISCUSSION}

Generally coinciding facial midline to maxillary dental midline is considered as normal which increases the esthetic quality of the face ${ }^{813}$. Similarly slight facial asymmetry and non-coincidence of facial and dental midlines are also considered as normal but the sense of normal or abnormal depends upon individual perception ${ }^{2}$. Thus the aim of this study was to evaluate the coincidence of midlines and severity of the discrepancies of those midlines.

From this study it was observed that majority of the individuals had non coinciding facial and dental midlines. Only $9.33 \%$ of total subjects $(6.66 \%$ of male and $12 \%$ of female), had perfectly coinciding facial midlines with maxillary midline. In contrast $47.9 \%$ of Pakistani population ${ }^{14}, 72.5 \%$ of Karnataka population ${ }^{11}$ and $85 \%$ of Caucasian ${ }^{15}$ had facial and maxillary dental midline coinciding. All of those studies considered only one parameter as facial midline which was similar to F2 facial midline of this present study. In our study, $15.66 \%$ in total (14\% male and $17.33 \%$ female) of the sample had F2 facial midline coincided with maxillary midline. Thus if we considered F2 as only facial midline then $24.99 \%$ Nepalese had coinciding facial and dental midline. Likewise $8 \%$ (10.66\% male and 5.33\% female) had F1 midline coinciding with maxillary midline. This showed that higher percentage of Nepalese population had F2 coinciding with maxillary midline than F1 midline. From Table 1 also it was observed that higher percentage had less than $1 \mathrm{~mm}$ of discrepancy of maxillary midline with F2 than F1 midline. F1 midline coincidence with maxillary midline was affected by the level of the eyes. Difference in eye level caused shift of perpendicular line away from the maxillary midline.

In the present study, $23.33 \%$ (25.33\% male and $21.33 \%$ female) had F1 and F2 facial midlines coinciding with each other but not with maxillary midline. This means in these subjects facial midlines are on normal position but the maxillary arch rotated from the normal position. Result also indicated that females had facial midlines shifted equally on either side of the maxillary midline but majority of males had facial midlines on left side of the maxillary midline (Table 3 ).

Similarly $7.66 \%$ (8.66\% male and $6.66 \%$ female) had increased shift of F2 facial midline than F1 midline, which meant they had the deviation of nose away from the maxillary midline. $11.66 \%$ (10.66\% male and $12.66 \%$ female) had decreased shift of F2 midline than F1 midline which meant they had the nose tip closer to the maxillary midline. This showed that deviated nose is one of the cause of facial and dental asymmetry. Study of Yi Jong Sook et al also indicated that deviated noses are responsible for the facial asymmetry ${ }^{16}$.

If we considered the result of Table 3 and 5 combined as midline deviation, then $42.66 \%$ of Nepalese had deviated midline in which $15 \%$ were right deviated and $27.66 \%$ were left deviated. In Pakistani population $52.1 \%$ had midline deviation and majority were on left side deviation ${ }^{14}$ whereas in Karnataka population $48.2 \%$ had midline shift and majority were right side deviation ${ }^{11}$. The study of Jain S. et al reported $77 \%$ of their subjects had midline shift ${ }^{17}$ but the study was done in individuals who came for orthodontic treatment. Similarly in Saudi population $42.5 \%^{18}$ had midline shift and mainly on right side deviation. The study done in female celebrities for smile analysis by Sulieman Al 
Johany et al had their midline deviation in $36 \%{ }^{19}$. Finally $24.33 \%$ of Nepalese (24\% male and 24.66\%female) had $F 1$ and F2 facial midline distributed on either side of the maxillary midline which indicates the non-coincidence of any of the midline with one another. This happened because these individual had different eye level, deviated nose and rotated maxillary arch.

\section{CONCLUSION}

Most of the Nepalese have non coinciding facial and dental midline. Females have more coinciding midlines in comparison to male. The shift of facial midlines are more towards left from the maxillary dental midline. It was also observed that coincidence of midlines are largely affected by level of eyes, deviation of the nose and transverse rotation of the maxillary arch.

\section{REFERENCES}

1. Bishara SE, Burkey PS, Kharouf JG. Dental and facial asymmetries: a review. Angle Orthod. 1994;64(2):89-98. PubMed

2. Cheong YW, Lo LJ. Facial asymmetry: etiology, evaluation, and management. Chang Gung medical journal. 2011;34(4):341-51. PubMed

3. Maheshwari S, Verma SK, Gaur A, Dhiman S. Diagnosis and management of facial asymmetries. Journal of Orthodontic Research. 2015;3(2):81-7. https://doi.org/10.4103/2321-3825.149054 Full Text

4. Severt TR, Proffit WR. The prevalence of facial asymmetry in the dentofacial deformities population at the University of North Carolina. The International journal of adult orthodontics and orthognathic surgery. 1997;12(3):171-6. PubMed

5. Proffit WR, Fields HW Jr, DM. S. Contemporary orthodontics. 2012;5th ed. St Louis: Elsevier-Mosby. Full Text

6. Williams RP, Rinchuse DJ, Zullo TG. Perceptions of midline deviations among different facial types. American journal of orthodontics and dentofacial orthopedics : official publication of the American Association of Orthodontists, its constituent societies, and the American Board of Orthodontics. 2014;145(2):249-55.https://doi.org/10.1016/j. ajodo.2013.02.034 PubMed

7. Bhateja NK, Fida M, A. S. Frequency of dentofacial asymmetries: a cross-sectional study on orthodontic patients. J Ayub Med Coll Abbottabad. 2014;26(2):129-33. PubMed

8. Khan M, Qamar K, Naeem S. Coincidence of facial midline with dental midline. Pakistan Oral \& Dental
Journal Vol 34, No 2 (June 2014). 2014;34:355. Full Text

9. Johnston $C D$, Burden DJ, Stevenson MR. The influence of dental to facial midline discrepancies on dental attractiveness ratings. European journal of orthodontics. 1999;21(5):517-22. https://doi. org/10.1093/ejo/21.5.517 [PubMed]

10. Miller EL, Bodden WR, Jr., Jamison HC. A study of the relationship of the dental midline to the facial median line. The Journal of prosthetic dentistry. 1979;41(6):657-60.https://doi.org/10.1016/00223913(79)90065-9 [PubMed]

11. Vivek Sharma, Meenakshi Khandelwal, Punia V. Correlation of facial to dental midline and maxillary to mandibular midline in Karnataka population. Annals and Essences of Dentistry. 2011;III(I):20-4. https://doi.org/10.5368/aedj.2011.3.1.1.4 Full Text

12. Hafezi F, Naghibzadeh B, Nouhi A, Yavari P. Asymmetric facial growth and deviated nose: a new concept. Annals of plastic surgery. 2010;64(1):4751. https://doi.org/10.1097/SAP.0b013e31819ae02d PubMed

13. Cardash HS, Ormanier Z, Laufer BZ. Observable deviation of the facial and anterior tooth midlines. The Journal of prosthetic dentistry. 2003;89(3):282-5. https://doi.org/10.1067/mpr.2003.68 [PubMed]

14. Khan M, Kazmi SR. Coincidence of dental midline with facial midline in a sample of Pakistani population. . Journal of the College of Physicians and Surgeons Pakistan. 2019;29(3):210-3.https://doi.org/10.29271/ jcpsp.2019.03.210 [Full Text]

15. Nold SL, Horvath SD, Stampf S, Blatz MB. Analysis of select facial and dental esthetic parameters. The International journal of periodontics \& restorative dentistry. 2014;34(5):623-9.https://doi. org/10.11607/prd.1969 [Full Text]

16. Yi JS, Jang YJ. Frequency and Characteristics of Facial Asymmetry in Patients With Deviated Noses. JAMA Facial Plast Surg. 2015;17(4):265-9.https://doi. org/10.1001/jamafacial.2015.0388 [PubMed]

17. Jain.S, Jain.V, A G. Prevalence Of Midline Shift In Orthodontic Patient. International Journal of Current Innovation Research. 2015;1(10):287-90. Full Text

18. Khan MF, Sharaz $S$, Shariff M, Alam MK, Binhomran FM, Almathami SA. Discord Between the Facial and Maxillary Midline and Intermaxillary Midline Among the Population of Asir, Saudi Arabia. Pesquisa Brasileira em Odontopediatria e Clínica Integrada. 2019;19. https://doi.org/10.4034/ PBOCI.2019.191.132 [Full Text]

19. Al Johany S, Alqahtani A, Alqahtani F, Alzahrani A. Evaluation of different esthetic smile criteria. The International journal of prosthodontics. 2011;24:6470. PubMed 